\title{
Genetics of Recurrent Early-Onset Major Depression (GenRED): Final Genome Scan Report
}

Peter Holmans, Ph.D.

Myrna M. Weissman, Ph.D.

George S. Zubenko, M.D., Ph.D.

William A. Scheftner, M.D.

Raymond R. Crowe, M.D.

J. Raymond DePaulo, Jr., M.D.

James A. Knowles, M.D., Ph.D.

Wendy N. Zubenko, Ed.D.

Kathleen Murphy-Eberenz, Ph.D.

Diana H. Marta, M.S.N.

Sandra Boutelle, M.S.

Melvin G. McInnis, M.D.

Philip Adams, Ph.D.
Madeline Gladis, Ph.D.

Jo Steele, B.A.

Erin B. Miller, M.S.

James B. Potash, M.D., M.P.H.

Dean F. MacKinnon, M.D.

Douglas F. Levinson, M.D.

Objective: The authors carried out a genomewide linkage scan to identify chromosomal regions likely to contain genes that contribute to susceptibility to recurrent early-onset major depressive disorder, the form of the disorder with the greatest reported risk to relatives of index cases.

Method: Microsatellite DNA markers were studied in 656 families with two or more such cases (onset before age 31 in probands and age 41 in other relatives), including 1,494 informative "all possible" affected relative pairs (there were 894 in. dependent affected sibling pairs). Analyses included a primary multipoint allele- sharing analysis (with ALLEGRO) and a secondary logistic regression analysis taking the sex of each relative pair into account (male-male, male-female, female-female).

Results: Genomewide suggestive evidence for linkage was observed on chromosome 15q25-q26 (at 105.4 centimorgans $[\mathrm{CM}]$ ). The authors previously reported genomewide significant linkage in this region in the first 297 families. In the secondary analysis, after empirical genomewide correction for multiple testing, suggestive linkage results were observed on chromosome $17 \mathrm{p} 12(28.0 \mathrm{cM}$, excess sharing in male-male and male-female pairs) and on chromosome 8p22. p21.3 (25.1 cM, excess sharing in male. male pairs).

Conclusions: These regions of chromosomes $15 q, 17 p$, and $8 p$ might contain genes that contribute to susceptibility to major depression and related disorders. Evidence for linkage has been reported independently in the same regions of chromosome $15 q$ for major depression and of chromosome $8 p$ for related per. sonality traits.

(Am J Psychiatry 2007; 164:248-258)

\begin{abstract}
I
n a genomewide linkage scan, families with at least a pair of ill relatives (other than parent-child pairs) were recruited, and DNA markers on all chromosomes were assayed to search for locations where ill subjects have inherited the same sequence variants (within families) more often than expected by chance. These markers are likely to be close to genes that contribute to disease susceptibility, which can then be identified by using other methods. The Genetics of Recurrent Early-Onset Depression (GenRED) sample was recruited to carry out a large-scale genome scan. In a preliminary analysis of 297 families (wave 1), significant linkage (corrected for genomewide analyses) was observed on chromosome 15q (1) (see Primary Linkage Analysis, below, for details). We report here that in all 656 families (waves 1 and 2), genomewide suggestive linkage (a result expected by chance once per genome scan) was observed on chromosome $15 q$ and also on chromosomes $17 \mathrm{p}$ and $8 \mathrm{p}$ in a planned second analysis accounting for the sex of each pair of relatives.
\end{abstract}

The lifetime prevalence of major depressive disorder is at least $10 \%$, with women affected twice as often as men (2-4). Twin studies estimate heritability at $40 \%-50 \%(5-11)$ or as high as $70 \%$ with repeated assessments (6). Adoption studies also suggest genetic factors (12-14). The mode of inheritance is unclear $(2,15)$. The relative risk to first-degree relatives versus comparison relatives is $2-3(16-18)$, but a further increase in relative risk is observed for probands with an age at onset in the 30 s or earlier $(15,17,19-24)$ or recurrent episodes $(6,22,25-27)$. The relative risk for recurrent and early-onset major depressive disorder is probably at least $4-5$ based on family studies $(16,22,24,28)$, although its prevalence in the general population is unknown. Because the power to detect a given gene is predicted by its effect on the relative risk (29), large-scale genetic studies of current early-onset major depressive disorder were proposed because it has the largest reported overall relative risk of any phenotype related to unipolar depression (30).

This article is featured in this month's AJP Audio and is discussed in an editorial by Dr. McGuffin and colleagues on p. 195. 
TABLE 1. Numbers of Informative Affected Relative Pairs ${ }^{a}$

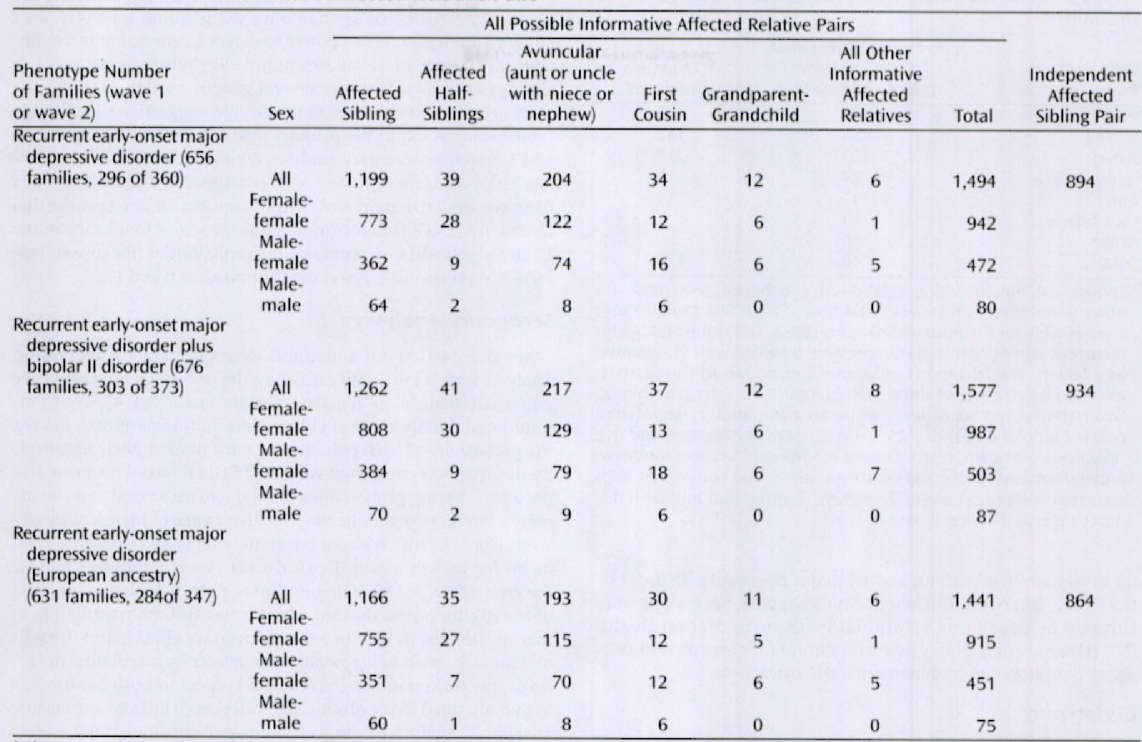

Shown are the numbers of informative affected relative pairs in each analysis broken down by sex, with inclusion of all possible pairs, as well as the number of statistically "independent" affected sibling pairs counting data supplement Table 1 (available online at http://ajp.psychiatryonline.org) pairs for a sibship with supplementary affected cases. The primary analysis considered all major depressive disorder pairs in 656 eligible families. The planned second analysis considered the same families, with the sex of the pair (male-male, male-female, femalefemale) entered as a covariate. Exploratory analyses considered the current early-onset major depressive disorder plus bipolar disorder II phenotype (676 families) and the current early-onset major depressive disorder phenotype in families of predominantly European ancestry only (631 families). Families were recruited at Columbia University ( $N=133)$, the University of Pittsburgh ( $N=119)$, the University of Pennsylvania ( $N=115)$, Rush University Hospital $(\mathrm{N}=113)$, Johns Hopkins University $(\mathrm{N}=98)$, and the University of Iowa ( $\mathrm{N}=98$ ). Self-reported ancestries were predominantly European (647 families), African American ( $\mathrm{N}=17)$, Hispanic $(\mathrm{N}=8)$, Asian ( $\mathrm{N}=3)$, and Sephardic Jewish ( $\mathrm{N}=1$ ).

\section{Method}

\section{Subjects}

Eligibility criteria, ascertainment, and assessment procedures have been previously described $(1,31)$. Briefly, all protocols were approved by local institutional review boards, and after complete description of the study to each subject, written informed consent was obtained. Probands were recruited through clinicians and by self-referrals in response to Internet, print, and broadcast announcements and screened by telephone to determine whether the proband and at least one sibling were likely to be eligible. Family members with possible mood disorders were interviewed by telephone or in person using the Diagnostic Interview for Genetic Studies (DIGS 3.0) (32) and the Family Interview for Genetic Studies (http://zork.wustl.edu/nimh). For each case, two research clinicians reviewed Diagnostic Interview for Genetic Studies and Family Interview for Genetic Studies data, an interview summary, and available psychiatric records and completed independent and consensus ratings of "best estimate" primary and secondary DSM-IV diagnoses (33), including age at onset and confidence levels; number of major depressive, manic, or hy. pomanic episodes; and ratings of severity, chronic versus remitting course, and temporal relationship to substance use.
Probands with current early-onset major depressive disorder had at least two lifetime major depressive episodes (persisting past age 18) or one episode lasting 3 or more years, with major role impairment, age of onset before age 31 , and high diagnostic confidence. We recruited all available ill family members (connected by first-degree relationships to other ill members) who met the same criteria, except with age of onset before 41 , because the risk of major depressive disorder increases through the $30 \mathrm{~s}$ in relatives of early-onset probands (12). Exclusion criteria were having bipolar I disorder, schizophrenia, or schizoaffective diagnoses; having a parent or sibling with suspected bipolar I disorder; or having a likely medical basis for the mood disorder. Subjects with antisocial personality or somatization disorders (which both proved rare in ascertained subjects) were also excluded because of the difficulty of diagnosing major depressive disorder with confidence in these individuals. Individuals with substance dependence were included if major depressive disorder started first or recurred after 2 years without dependence (or 1 year for relatives). If the initial proband's consensus diagnosis was bipolar II disorder, the family was excluded, but bipolar II disorder relatives were recruited (but excluded from the primary analyses) because the relationship of major depressive disorder to bipolar II disorder remains unclear.

Blood specimens were obtained from interviewed subjects, available parents, and (if fewer than two parents were available) 
TABLE 2. Relationships of Genotyped Individuals to Probands $^{\mathrm{a}}$

\begin{tabular}{lcc}
\hline $\begin{array}{l}\text { Relation to } \\
\text { Proband }\end{array}$ & $\begin{array}{c}\text { Recurrent Early-Onset } \\
\text { Cases of Major } \\
\text { Depressive Disorder }\end{array}$ & $\begin{array}{c}\text { "Diagnosis } \\
\text { Unknown" }\end{array}$ \\
\hline Proband & 656 & 0 \\
Sibling & 856 & 142 \\
Parent & 102 & 238 \\
Aunt or uncle & 24 & 5 \\
Child & 47 & 11 \\
Half-sibling & 13 & 2 \\
Other & 50 & 30 \\
Total & 1,748 & 428 \\
\hline
\end{tabular}

a Shown are the biological relationships between probands and other genotyped individuals (total $\mathrm{N}=2,176$ ) in 656 families that were eligible for the primary linkage analysis. Only individuals with recurrent early-onset major depressive disorder were designated as affected. The "diagnosis unknown" individuals in this analysis included 24 relatives of those with bipolar II disorder (16 siblings, two parents, and six others), while an additional 21 genotyped cases of bipolar II disorder, 25 recurrent early-onset cases, and five "diagnosis unknown" relatives were members of families that were only informative in the exploratory analysis that considered both recurrent early-onset major depressive disorder and bipolar II disorder cases as affected (see text).

up to two siblings without known major depressive disorder by the Family Interview for Genetic Studies report. Specimens were shipped by courier to a National Institute of Mental Health (NIMH) repository (http://www.rucdr.org) for creation and storage of lymphoblastic cell lines and DNA extraction.

\section{Genotyping}

Genotyping was carried out at the Center for Inherited Disease Research with standard methods for fluorescently labeled microsatellite markers (http://www.cidr.jhmi.edu). Details of the multistage genotyping effort and the combining of genotypes across stages are available in the data supplement text (available online at http://ajp.psychiatryonline.org). Briefly, 418 markers were genotyped (392 of them in wave 1 families and 404 in wave 2) at mean 9 centimorgans $(\mathrm{cM})$ spacing and mean marker heterozygosity of 0.77 . There were $3.29 \%$ missing genotypes (of 956,220 ), with $0.04 \%$ genotypewise errors based on duplicated genotypes and $0.32 \%$ detected Mendelian inconsistencies, including pedigree or specimen errors.

\section{Error Checking}

Pedigree structure and sample swap errors were detected by PEDCHECK analysis of 15 markers (34) and then with RELCHECK analysis of all markers (35). Genotypes were excluded from analyses for family marker combinations with Mendelian inconsistencies or if SIBMED (36) estimated a $70 \%$ probability of error $(\mathrm{N}=72)$.

\section{Primary Linkage Analysis}

Additional details of statistical methods are available in the data supplement text. Briefly, multipoint allele-sharing analysis (ALLEGRO [37]) was carried out in 656 informative families with current early-onset major depressive disorder diagnoses and marker locations from the deCODE map (38) or by interpolation from Marshfield locations (http://research.marshfieldclinic.org/ genetics/). Analyses considered all possible informative relative pairs, with a weighting function that is approximately midway between equal weighting for each pair versus for each family (39). We computed genomewide (corrected) significance levels by simulating 5,000 replicates, assuming no linkage and counting the number of "hits" per genome (at least $30 \mathrm{cM}$ apart) that exceeded each observed Z likelihood ratio score statistic of Kong and Cox $\left(Z_{\perp R}\right)(40)$. Significant linkage was defined as a result observed by chance in $5 \%$ or fewer genome scans, and suggestive linkage, as a result, expected no more than once per genome scan (41). This study group has excellent power to detect a genetic locus responsible for an approximately $30 \%$ populationwide increase in risk to siblings of probands under several genetic models (31). For the three results that achieved genomewide suggestive significance (chromosome $15 q$ in the primary analysis and chromosomes $8 p$ and $17 \mathrm{q}$ in the secondary analysis, taking sex into account), linkage analyses were repeated with sex-specific marker locations from the deCODE map and with the option for sex-specific distances in ALLEGRO to recompute linkage scores for chromosome 15 and identical-by-descent sharing probabilities (for subsequent logistic regression analyses) for chromosome 8 and 17 .

\section{Secondary Analyses}

We also carried out a planned secondary logistic regression analysis with a covariate encoding the sex of each informative pair (male-male, male-female or female-female) $(1,42,43)$. Computational details are available in data supplement text. Briefly, the probability of each pair sharing each marker allele identicalby-descent was computed (with ALLEGRO) based on prior and posterior sharing probabilities $(29,44)$ and expressed as a logistic regression on two parameters: the divergence of identical-by-descent from the null without covariate effects and the three-level factor for sex of the pair. Two lod scores were computed: one for the covariate effect (allowing for linkage), by calculating the ratio of the likelihood maximized with respect to both parameters to that maximized in the absence of covariate effects, and the second for linkage allowing for covariate effects, by calculating the ratio of the likelihood maximized with respect to both parameters to that obtained in the absence of both overall linkage and covariate effects. Analysis of the X chromosome considered the maternally inherited chromosome for affected sibling pairs. Genomewide empirical significance levels were determined for linkage allowing for covariate effects with 5,000 simulations of genotypes for the group, assuming no linkage, with actual marker locations, allele frequencies, affected status, and sex. As a correction for carrying out a secondary analysis, we first determined the empirical significance of the largest peak on each chromosome, with allowance for covariate effects, and then counted the number of peaks observed in each simulated genome that achieved the same empirical significance level either with or without covariate effects modeled. We also computed empirical chromosomewide p values for the covariate effect by randomly permuting covariate values among affected individuals and determining the significance of the difference between the lod score with and without the sex covariate. Because this depends on evidence for linkage on the chromosome without allowance for the covariate, a genomewide $\mathrm{p}$ was estimated by dividing the $\mathrm{p}$ by the chromosome's proportion of genome length.

Additional exploratory analyses included repeating the primary ALLEGRO analysis while considering both current early-onset major depressive disorder and bipolar II disorder cases as affected and repeating the ALLEGRO and sex covariate analyses for current early-onset major depressive disorder in families of predominantly European ancestry (by self-report of up to four ethnicities for each parent). Familial clustering of comorbid features was examined by computing odds ratios for each feature for occurrence in the first and second sibling in each sibship. Finally, several analyses were undertaken to explore possible factors that might account for the large difference in linkage results on chromosome 15 in waves 1 and 2 , including differences in clinical symptoms and comorbid diagnoses between wave 1 and 2 families ( $t$ tests and chi-square tests) and examination of whether identical-by-descent sharing in affected relative pairs differed significantly across study sites (cross-site heterogeneity), with the 
TABLE 3. Comorbid Disorders and Demographic and Clinical Characteristics of the Study Group ${ }^{\mathrm{a}}$

\begin{tabular}{|c|c|c|c|}
\hline \multirow{2}{*}{$\begin{array}{l}\text { Variable } \\
\text { Comorbid disorders }\end{array}$} & \multicolumn{3}{|c|}{ Characteristic } \\
\hline & $N$ & & Percent \\
\hline Panic disorder & 442 & & 25 \\
\hline Obsessive-compulsive disorder & 165 & & 09 \\
\hline Social anxiety disorder & 250 & & 14 \\
\hline Any anxiety diagnosis & 686 & & 39 \\
\hline Alcohol abuse & 198 & & 11 \\
\hline Alcohol dependence & 215 & & 12 \\
\hline Substance abuse & 163 & & 09 \\
\hline Substance dependence & 191 & & 11 \\
\hline Alcohol or substance abuse & 316 & & 18 \\
\hline Alcohol or substance dependence & 403 & & 23 \\
\hline Alcohol or substance abuse or dependence & 589 & & 34 \\
\hline Nicotine dependence & 310 & & 18 \\
\hline Clinical and demographic features & N & & Percent \\
\hline Sex (female/male) & $1,392 / 356$ & & $80 / 20$ \\
\hline Major depressive disorder with psychotic features & 72 & & 04 \\
\hline Chronic course $e^{b}$ & 520 & & 30 \\
\hline \multirow[t]{2}{*}{ Suicide attempt (>minimal intent) } & 284 & & 16 \\
\hline & Mean & SD & Median \\
\hline Age at onset (years at first major depressive episode) & 19.0 & 7.3 & 18 \\
\hline Number of episodes & 6.7 & 10.3 & 4 \\
\hline Longest episode (days) & 723.5 & 1243.7 & 365 \\
\hline Age at interview (years) & 42.0 & 12.5 & 42 \\
\hline Age at onset of major depressive disorder with psychotic features (years) & 28.2 & 10.2 & 26 \\
\hline Number of eight major depressive disorder criteria met (worst episode) & 6.7 & 1.2 & 7 \\
\hline
\end{tabular}
of eight major depressive disorder criteria met (worst episode)

a Shown are the distributions of comorbid psychiatric disorders and demographic and clinical variables for cases of recurrent early-onset major depressive disorder in 656 families eligible for the primary linkage analysis.

befers here to the consensus diagnosticians' global rating of lifetime course of depression (see text).

logistic methods described above for the analysis of sex effects but with site as the covariate.

\section{Changes in the Data Set for Wave 1 Families}

The results for wave 1 differ slightly from those published previously (1) because there were 26 additional subjects from 23 wave 1 families and 12 changes in diagnostic status from further data cleaning (three to affected and nine to unaffected status), which made one family uninformative (i.e., there were 297 wave 1 families previously versus 296 here). Details are available in the data supplement text. With or without these changes, chromosome $15 q$ produced genomewide significant linkage in wave 1 families and suggestive linkage in the total group, and chromosomes $8 p$ and $17 p$ produced suggestive evidence for linkage in the secondary analysis.

\section{Data Sharing}

The NIMH Human Genetics Initiative web site (http:// zork.wustl.edu/nimh) describes how scientists can obtain de-identified clinical information and marker genotypes from this study.

\section{Results}

\section{Description of the Eligible Families}

Table 1 shows the numbers of families and of affected relative pairs for the three sets of families used in the analyses (families that were informative with current early-onset major depressive disorder cases considered as affected, with bipolar II disorder cases added, or with current earlyonset major depressive disorder only but restricted to European ancestry). All types of pairs were considered in the analyses. Three additional families were excluded (for identical or unrelated genotypes in the two siblings). The table note provides information about distribution of families by recruitment site and self-reported ethnicity. Our re- cruitment concentrated on families from a single broad ethnic group (Europeans) to reduce genetic heterogeneity, but volunteers with other ancestries were accepted.

In the 656 families in the primary current early-onset major depressive disorder analysis, there were 1,748 affected, interviewed genotyped individuals, including 1,720 with recurrent major depressive disorder and 28 with one major depressive episode lasting 3 years or longer. The other 428 genotyped relatives were treated as "diagnosis unknown," including 24 with bipolar II disorder and 404 who provided only blood specimens or were interviewed and received ineligible diagnoses. Relationships of family members to probands are shown in Table 2 . In the 20 families that were eligible only when the bipolar II disorder cases were added, 51 individuals were genotyped (25 current early-onset major depressive disorder cases, including 20 probands and five parents, 21 bipolar II disorder siblings, and four siblings and one parent with "diagnosis unknown"). Table 3 provides information on comorbid disorders and on clinical, demographic, and courseof-illness variables. Cross-site interrater reliability and agreement of clinical ratings have been previously described (31).

\section{Primary Linkage Analysis}

Figure 1 illustrates genomewide $Z_{\mathrm{LR}}$ for the primary linkage analysis. Table 4 shows the maximum scores on each chromosome. Genomewide suggestive linkage (a score expected by chance once or less per genome scan) was observed on chromosome 15q25-q26 at $105.43 \mathrm{cM}$, between markers D15S652 (99.9 cM, 90.247 megabase) 


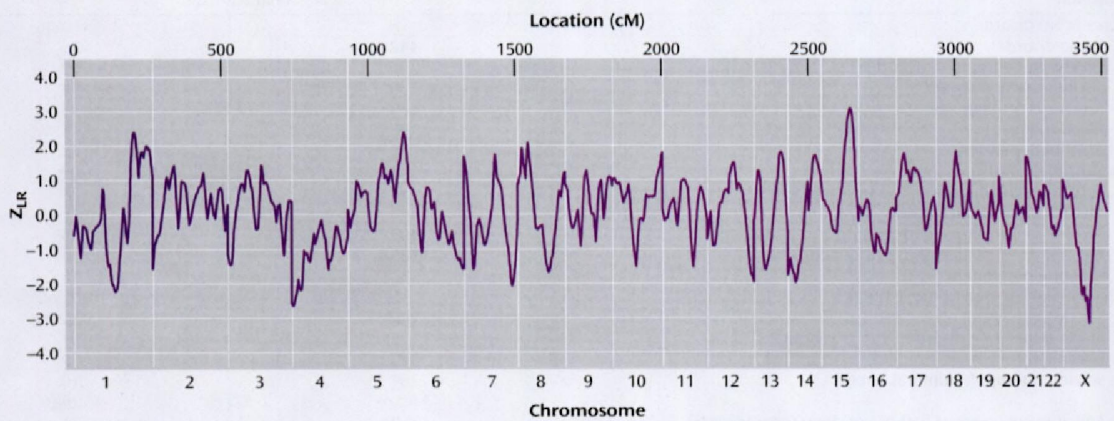

a Shown are $\mathrm{Z}$ likelihood ratio score statistics of Kong and Cox (40) across the genome for the primary multipoint linkage analysis (with ALLEGRO) with recurrent early-onset major depressive disorder cases considered affected.

and D15S816 (110.9 cM, 92.750 megabase). The genetic map is substantially different for men and women in this region, but similar results were observed when the analysis was repeated with sex-specific map distances $\left(Z_{\mathrm{LR}}=\right.$ 3.04 , lod=2.0). Results are shown in Figure 2 for $15 q$ analyses for wave 1, wave 2, all families, and European families, and details are shown in data supplement Table 1 and Table 2 . We previously reported a wave $1 Z_{\mathrm{LR}}$ of 4.14 at 103.2 cM on $15 q$ (1). Here, with the group changes described above and in data supplement text, the $Z_{L R}$ was 3.93 at $105.4 \mathrm{cM}$ (0.049 expected genomewide false positive peaks). No nominally significant evidence for linkage was observed on $15 q$ in wave 2 . The analysis of all families was considered primarily a priori. Interpretation of this result must await linkage fine mapping. No other region produced genomewide significant or suggestive evidence for linkage. Linkage information content with ALLEGRO's exponential measure averaged 0.699 across the genome (evaluating 10 points per interval) and 0.712 under the $15 q$ peak $(30 \mathrm{cM})$.

\section{Linkage Analysis With Sex of the Pair as a Covariate}

Table 4 and Figure 3 summarize these results. For the primary outcome ("Linkage With Sex Effect"), the number of expected genomewide peaks of the observed size after correction for multiple testing was $<1$ for chromosomes 17 p12 (28.04 cM near marker D17S974), which came very close to the genomewide 0.05 level, and 8p22-p21.3 (25.09 cM, near D8S1106). As shown in the last column of Table 5, increased identical-by-descent sharing was observed on $8 p$ only in the small number of male-male pairs, while on $17 p$, it was observed in male-male and male-female pairs. Results on $8 p$ and $17 q$ were similar when sex-specific map distances were used to combine identical-by-descent sharing probabilities; with sex-averaged versus sex-spe- cific maps, the difference between the lods allowing and not allowing for sex was 3.54 versus 3.47 for $17 \mathrm{q}$ and 2.12 versus 2.03 for $8 \mathrm{p}$ with almost identical identical-by-descent sharing probabilities. Without covariates, the lod score on chromosome 15 was suggestive, consistent with the primary analysis.

Estimated empirical significance is also shown for the covariate effect (how often one would observe by chance a given increase in lod score). Chromosome 6p (31.19 cM) produced a suggestive result with identical-by-descent sharing increased in male-male pairs and decreased below $50 \%$ in male-female pairs. This finding might be less plausible biologically, although in theory it could occur if an allele increased the risk of major depressive disorder in men and decreased it in women or if two or more loci in one region had different sex effects.

\section{Exploratory Analyses}

When bipolar II disorder cases were added, maximum scores for the primary analysis (data supplement Table 3) and secondary analysis (data not shown) were similar but slightly lower. For example, the maximum $\mathrm{Z}_{\mathrm{LR}}$ on chromosome $15 \mathrm{q}$ was reduced from 3.05 to 2.80 . Note that only a few families had more than one case of bipolar II disorder, so separate linkage analyses of this disorder were not feasible.

Because allele frequency estimates can affect linkage scores when parental genotypes are unavailable (45-49), inclusion of families from several ethnic backgrounds with different frequencies could bias the results. Thus, European families were analyzed separately. Scores were similar in most regions and were higher on $15 q$ : for wave 1 , the $Z_{\mathrm{LR}}$ was 4.31 in European families (105.43 cM, genomewide expected peaks $=0.014$ ) versus 3.93 for all ethnicities; in all 631 European families, the $Z_{L . R}$ was 3.43 (106.53 $\mathrm{cM}$, genomewide expected peaks $=0.27$ ) versus 


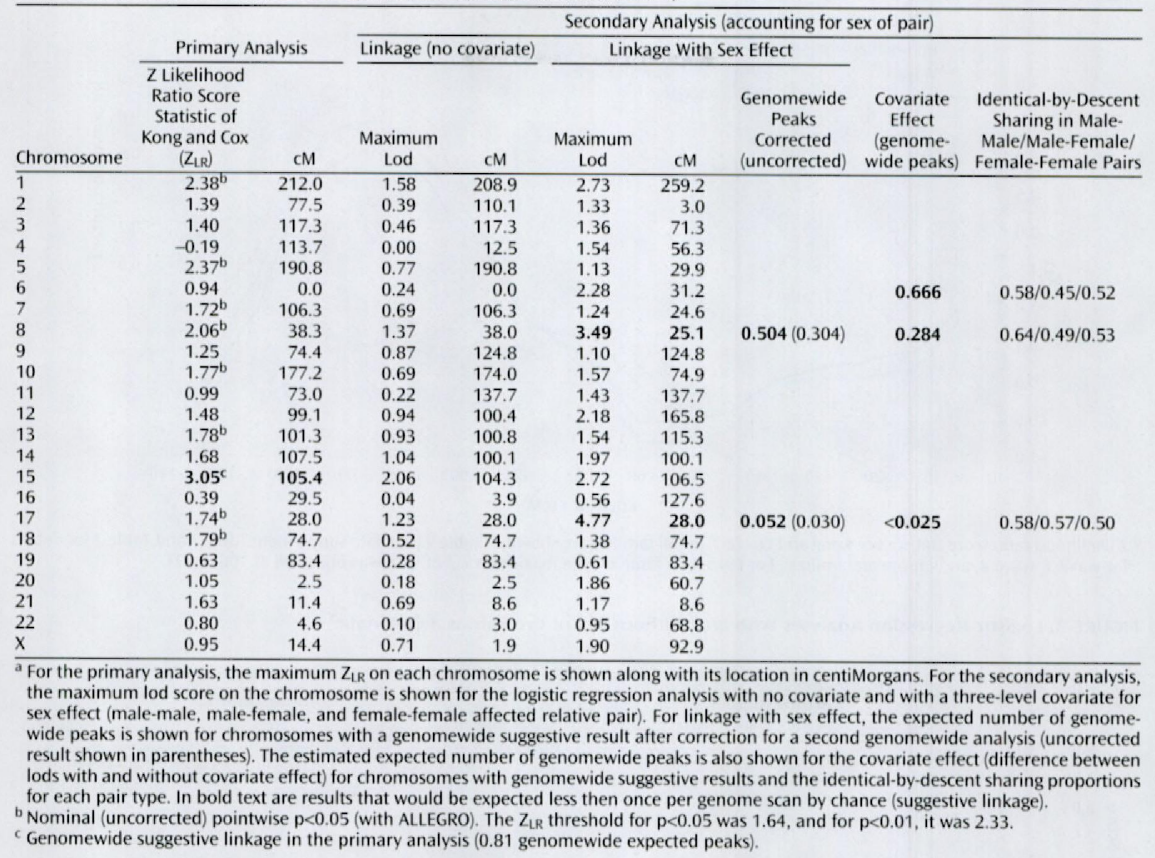

3.05 (expected peaks $=0.81$ ) for all ethnicities. Similar increases were seen in secondary analyses (data supplement text and Table 4 and Table 5).

We also examined linkage with sex covariate effects on chromosome 12q, where significant linkage to mood disorders was reported in men at $110 \mathrm{cM}(50)$. Here, identical-by-descent sharing was increased in male-male $(0.59)$ versus male-female $(0.52)$ and female-female (0.53) pairs from $100 \mathrm{cM}$ to $113 \mathrm{cM}$, but this effect did not reach suggestive genomewide significance. Note, however, that in the 62 families that were informative for linkage when only male cases were considered affected, nominally significant evidence for linkage (i.e., without genomewide correction) was observed in the previously reported region, with the peak score at $97.84 \mathrm{cM}$ (lod= $0.86, \mathrm{p}<0.03)$.

Clinical differences were observed between wave 1 and 2 families. Wave 1 cases had earlier age at onset $(t=$ 2.18, $\mathrm{df}=1713.7, \mathrm{p}=0.03$ ), more major depressive episodes $(\mathrm{t}=4.39, \mathrm{df}=1769.5, \mathrm{p}=0.00001)$, and more panic attacks $(t=2.72, d f=1673.3, p<0.007)$, whereas wave 2 cases were more likely to be rated as having a chronic course $\left(\chi^{2}=11.26, \mathrm{df}=1, \mathrm{p}=0.0008\right)$, although the two sets of cases did not differ in substance dependence, abuse, or gender. However, these differences did not appear to predict chromosome $15 \mathrm{q}$ linkage. For example, when families from each site were analyzed separately, the Philadelphia and Pittsburgh sites produced the greatest evidence for linkage in wave 1 , but for both sites, wave 1 cases had slightly older ages at onset $(0.05<\mathrm{p}<0.10$ for each site), whereas all of the other variables mentioned were not significantly different except for more episodes occurring in wave 1 families for Pittsburgh but not Philadelphia. Comorbid diagnoses aggregated in families as expected in analyses of sibling-sibling concordance in independent affected sibling pairs, with significant odds ratios observed for panic disorder (odds ratio $=2.16,95 \% \mathrm{CI}[95 \%$ confidence interval] $=1.5$ 3.1 ) : panic with agoraphobia (odds ratio $=4.51,95 \% \mathrm{CI}=$ 2.43-8.37); alcohol dependence (odds ratio $=3.15,95 \%$ $\mathrm{CI}=1.86-5.35$ ), substance dependence (odds ratio $=2.54$, $95 \% \mathrm{CI}=1.43-5.41$ ), obsessive-compulsive disorder (odds ratio $=2.66,95 \% \mathrm{CI}=1.21-4.22$ ), nicotine dependence (odds ratio $=2.46,95 \% \mathrm{CI}=1.59-3.82$ ), and nicotine persistence (odds ratio $=4.37,95 \% \mathrm{CI}=3.05-6.26$ ). 
FIGURE 2. Chromosome 15 Linkage Results ${ }^{a}$

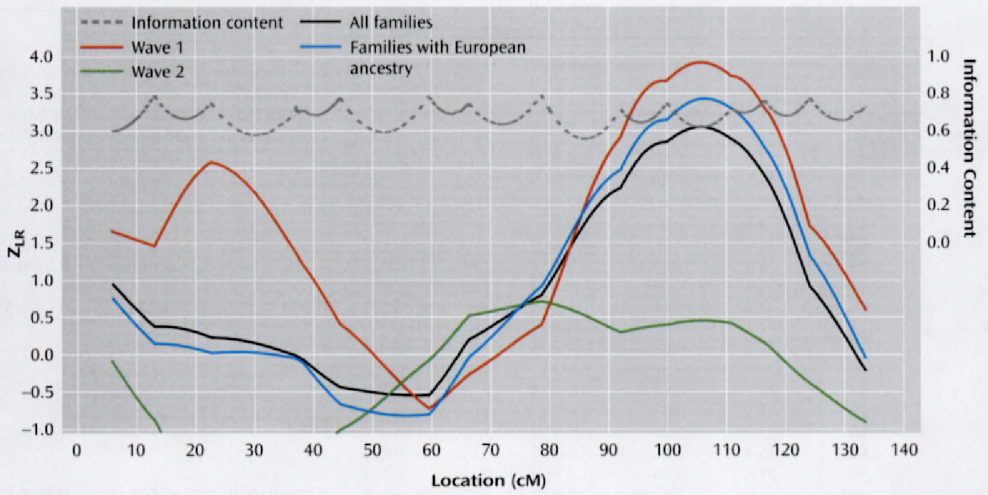

a Z likelihood ratio score statistics of Kong and $\operatorname{Cox}\left(Z_{I R}\right)$ for all families are shown in Table 4 (see data supplement Table 1 and Table 2 for details for wave 1, wave 2, and European families). For European families, the maximum $Z_{L R}$ of 3.43 was observed at 106.53 cM.

\section{FIGURE 3. Logistic Regression Analyses With and Without Sex of the Pair as a Covariate}

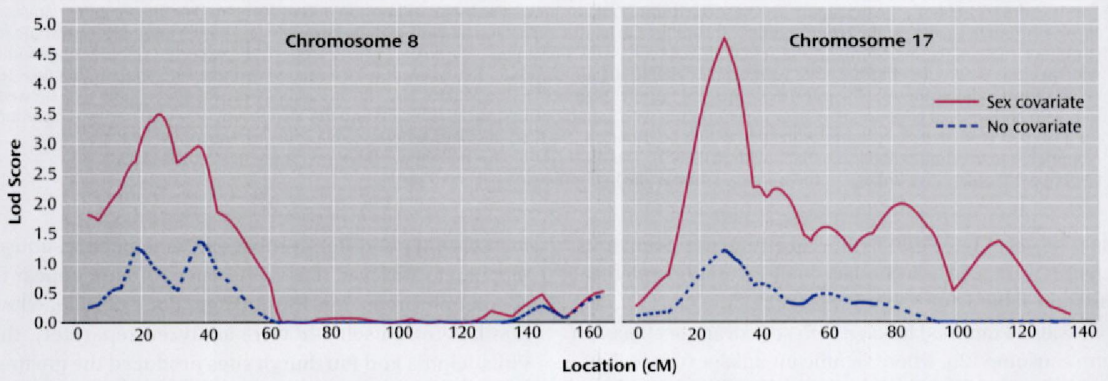

a Shown for chromosomes 8 and 17 are lod scores from logistic regression allele-sharing analyses of all possible informative affected relative pairs, with and without a covariate coding the sex of the pair (male-male, male-female, female-female). Significance levels are shown in Table 4.

More detailed logistic regression analyses of the effects of clinical covariates on linkage results will be presented elsewhere.

No significant cross-site heterogeneity was observed for identical-by-descent sharing in affected relative pairs on chromosome $15 \mathrm{q}$ (maximum lod score assuming homogeneity $=2.06$ at $98.51 \mathrm{cM}$, identical-by-descent $=0.537$; maximum lod score assuming site heterogeneity $=3.87$ at $98.51 \mathrm{cM}, \mathrm{p}=0.41$ ).

\section{Discussion}

In this genome scan analysis of families with multiple cases of recurrent early-onset major depressive disorder, genomewide suggestive linkage was observed on chromosome $15 q$ in the primary analysis and on chromosomes $17 p$ and $8 p$ in the secondary analysis after we accounted for the sex of the affected pair. The results suggest that no genetic locus makes a large contribution to the overall risk of major depressive disorder, that multiple loci (including some in these regions) may contribute to risk, and that the contribution of some loci may be sex dependent.

With use of a 9-cM microsatellite marker map, evidence for linkage was significant in wave 1, did not achieve nominal significance in wave 2 , and was suggestive in the total group. There are several possible explanations (1). The initial $15 \mathrm{q}$ finding could have been a false positive result (2). There might be differences in the genetic susceptibilities 


\begin{tabular}{|c|c|c|c|c|}
\hline Study & $\begin{array}{c}\text { Number } \\
\text { of } \\
\text { Families }\end{array}$ & Comments & Overlap With Present Results ${ }^{b}$ & $\begin{array}{c}\text { Other } \\
\text { Overlap }\end{array}$ \\
\hline
\end{tabular}

Linkage studies of major

depressive disorder

and related diagnoses

Zubenko et al. (53)

81 Five phenotypic models from recurrent earlyonset major depressive disorder to all mood disorders \pm covariates, including sex

Camp et al. (55)

Same families as reference 49 but restricted to recurrent early-onset major depressive disorder (onset before 31 ); \pm anxiety disorders as affected; separate analyses of men and women
Abkevich et al. (50)

McGuffin et al. (56)

Present study
Multiple cases of recurrent major depressive disorder; counted bipolar I and II disorder relatives as affected; separate analyses of men and women

Recurrent early-onset major depressive disorder; no age-at-onset restriction (but average age at onset was in the early 20s)

Recurrent early-onset major depressive disorder; secondary analysis with sex covariate

$11 q, 18 q$

15q: highest lod $(2.88,121 \mathrm{cM})$, men $3 \mathrm{q}, 4 \mathrm{q}, 18 \mathrm{q}$

$12 \mathrm{q}$ (men)

15q: fifth highest lod $(1.14,88.2 \mathrm{cM})$

$12 q$

15q: suggestive (105.4 cM), all families: 17p: suggestive (28 cM), male-male, male-female pairs; 8 : suggestive $(25.1 \mathrm{cM})$, male-male pairs; 6p: possible sex effect (31.2 $\mathrm{cM})$, male-male pairs

Linkage studies of depression-related personality measures Cloninger et al. (58)

Neale et al. (60)

Nash et al. (59)

105

129

283

Fullerton et al. (54)
Harm avoidance

Neuroticism (nicotine-dependence study sample)

Neuroticism; extremely concordant and discordant sibling pairs design

561 Neuroticism; extremely concordant and discordant sibling pairs design 8p: Highest lod $(3.2,23.5 \mathrm{cM})$

6p: Highest $\operatorname{lod}(2.7,61 \mathrm{cM})$

8p: Best result, men ( $p<0.002,15.2$ $\mathrm{cM})$ and seventh best, all families $(\mathbf{p}<0.002)$
$1 \mathrm{q}, 3 \mathrm{q}$

$1 \mathrm{q}, 4 \mathrm{q}$,

$11 q, 12 q$ (women)

\footnotetext{
Published linkage studies of major depressive disorder or related personality traits are listed in order of graup size.

b Shows the present results and possibly overlapping results in other studies.

'Lists other chromosomal regions that produced one of the most positive results in more than one study (see references for details).
}

of wave 1 and 2 families, although we have tried and (so far) failed to identify clinical differences between the two waves that predict $15 q$ linkage (3). The wave 1 result could represent a true positive finding but with an overestimate of the genetic effect. For complex disorders, initial reports of significant linkage are often upwardly biased $(51,52)$ because the gene effects are small, so that thousands of families might be needed to estimate and then replicate each true effect. Smaller samples give more variable results: by analogy, in 10,000 coin flips, the proportion of heads will be $48.6 \%-51.4 \%$ (close to the true value) around $95 \%$ of the time, but in 50 flips, the range will be $36 \%-64 \%$ (i.e., large under- and overestimates will be common). Thus, the most significant observed result in a small group is often a true signal that will not reliably be replicated in other small samples but will emerge as a true but smaller effect in very large samples. Further evaluation of the $15 q$ finding will require studying our group with more markers to increase informativeness and comparison or metaanalysis of results across multiple genome scans.

Two chromosomal regions (17p and $8 p$ ) produced suggestive evidence for linkage with a sex effect. Bierut et al. (5) reported greater heritability of major depressive disor- der in women than in men. Kendler et al. (7) supported this finding for broad but not narrow major depressive disorder criteria, concluding that major depressive disorder is probably more heritable in women, with a correlation of 0.5-0.6 for major depressive disorder genetic risk factors in men and women. Sex-specific evidence has been reported for linkage to major depressive disorder $(50,53)$ and to the related trait of neuroticism (54). Here the result on $17 \mathrm{p}$ is particularly interesting because it approached genomewide significance. It was attributable to increased allele sharing in male-male and male-female pairs, which might occur if a sequence variant increased risk more (but not exclusively) in men so that families with a male case would be more likely to be carrying the variant(s). Our findings on $17 \mathrm{p}$ and $8 \mathrm{p}$ could represent either false positives in a small male subgroup or important clues to sexspecific gene effects.

Table 5 summarized published linkage studies of major depressive disorder or related personality traits. In two studies of major depressive disorder $(55-57)$, one of the highest lod scores was observed on chromosome $15 q$, whereas on $8 \mathrm{p}$, a study of harm avoidance observed its highest score (58) and one of neuroticism observed its 


\section{Patient Perspective}

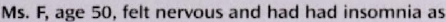
a child and lifelong social phobia. Since her first major depressive episode at 17 , she had had a chronically depressed mood. Several times per year, she had episodes of increased appetite, insomnia with wakening at night, poor concentration, a lack of enjoyment in activities, a low energy level, slowed speech, and a restless and tense feeling. Changes in antidepressant medication sometimes led to periods of improvement. Three of Ms. F's relatives committed suicide, and she took overdoses of pills five times. Asked to describe depression, she said, "It's hard to explain, but I'd rather have a physical pain than that pain."

highest score in men (54). Another neuroticism scan (59) reported its highest lod on $6 \mathrm{p}$, although it was somewhat far from the present result. Table 5 also lists regions where other studies reported overlapping results. Full assessment of the pattern of results across studies must await the appearance of more data, linkage fine mapping, and formal meta-analyses or combined analyses.

Some of these chromosomal regions have been of interest to investigators studying other psychiatric disorders. Evidence for linkage to schizophrenia has been reported in the same regions of chromosomes $6 p$ and $8 p(61)$, with our peaks occurring close to the schizophrenia candidate gene DTNBP1 on $6 p$ but not to the candidate gene NRG1 on 8p (62). As noted, our study did produce some evidence to support the finding of linkage to major depressive disorder in men on chromosome $12 \mathrm{q}(50)$. However, we did not observe any evidence for linkage on chromosome $2 \mathrm{q}$, where linkage was previously reported for several alternative major depressive disorder phenotypes in a smaller independent sample of families (53), or near several genes whose involvement in mood disorders is currently under intensive study, such as the genes encoding the serotonin transporter (SLC6A4 on more distal $17 \mathrm{q}$ ), serotonin receptor $2 \mathrm{~A}(13 \mathrm{q})$, and brain-derived neurotrophic factor (11p) (63), or in previously reported significant linkage regions for bipolar disorder, such as those on chromosomes $6 q$ and $8 \mathrm{q}(64)$. However, it is possible that major depressive disorder susceptibility genes will be discovered in some of these regions using genetic association methods that are more powerful than linkage analysis.

In conclusion, linkage analysis of 656 families demonstrated genomewide suggestive linkage on chromosome $15 q$ and also on chromosomes $17 p$ and $8 p$ when the sex of the affected relative pair was taken into account. Further study of regions producing evidence for linkage in studies of major depressive disorder and related traits could lead to the identification of genes contributing to susceptibility to severe depressive disorders.

Received April 9, 2006; revision received Sept. 22, 2006; accepted Oct. 12, 2006. From the Biostatistics and Bioinformatics Unit, Wales College of Medicine, Cardiff University, Cardiff, UK; the Department of Psychiatry, College of Physicians and Surgeons, Columbia University, New York State Psychiatric Institute, New York; the Department of Psychiatry, University of Pittsburgh, Pittsburgh; the Department of Psychiatry, Rush University Medical Center, Chicago; the Department of Psychiatry and Mental Health Clinical Research Center, University of Iowa, lowa City; the Department of Psychiatry. Johns Hopkins University, Baltimore; the Department of Psychiatry and Center for Neurobiology and Behavior, University of Pennsylvania, Philadelphia; and the Department of Psychiatry and Behavioral Sciences, Stanford University, Stanford, Calif. Address correspondence and reprint requests to Dr. Levinson, Department of Psychiatry and Behavioral Sciences, Stanford University School of Medicine, 701A Welch Rd., Suite 3325, Palo Alto, CA 94304-5797; dflevastanford.edu (e-mail).

Supported by NIMH grants 5R01-MH-059542 (to Dr. Crowe), 5R01MH-059552-04 (to Dr. DePaulo), 5R01-MH-061686 (to Dr. Levinson while at the University of Pennsylvania), 5R01-MH-059541 (to Dr. Scheftner), 5R01-MH-060912 (to Dr. Weissman), and 5R01-MH060866 (to Dr. Zubenko).

All principal investigators contributed to the design of the project and supervised the collection of pedigrees at their sites by following a common protocol. Individual sites assumed responsibility for specific studywide functions, including study coordination (University of Pennsylvania), data management (Johns Hopkins University), clinical quality-control site visits (Rush University Medical Center), interrater reliability assessment (University of lowa and Columbia University/New York State Psychiatric Institute), and DNA specimen management and quality control (Dr. Knowles at Columbia University/New York State Psychiatric Institute). Dr. Holmans assumed primary responsibility for statistical analyses. Genotyping services were provided by the Center for Inherited Disease Research. The center is fully funded through a federal contract from NIH to Johns Hopkins University, contract number N01-HG-65403. The NIMH Cell Repository at Rutgers University and the NIMH Center for Collaborative Genetic Studies on Mental Disorders made essential contributions to this project.

The authors thank the families who participated in this project and the clinicians who facilitated the referral of participants to the study.

Dr. Mcinnis has been on the speaker's bureau and received honoraria from Pfizer, AstraZeneca, GlaxosmithKline, and the France Foundation Dimedix. Dr. Weissman has received investigator-initiated grants from GlaxoSmithKline, Eli Lilly, NIMH, NIDA, the Macy Foundation, and NARSAD. Dr. Crowe has consulted with a law firm defending Pfizer in lawsuits against Zoloft. All other authors report no competing interests.

\section{References}

1. Holmans P, Zubenko GS, Crowe RR, DePaulo JR Jr, Scheftner WA, Weissman MM, Zubenko WN, Boutelle S, Murphy-Eberenz K, MacKinnon D, Mclnnis MG, Marta DH, Adams P, Knowles JA, Gladis M, Thomas J, Chellis J, Miller E, Levinson DF: Genomewide significant linkage to recurrent, early-onset major depressive disorder on chromosome 15q. Am J Hum Genet 2004; 74 : 1154-1167

2. Moldin SO, Reich T, Rice JP: Current perspectives on the genetics of unipolar depression. Behav Genet 1991; 21:211-242

3. Kessler RC, McGonagle KA, Zhao S, Nelson CB, Hughes M, Eshleman S, Wittchen HU, Kendler KS: Lifetime and 12-month prevalence of DSM-III-R psychiatric disorders in the United States: results from the National Comorbidity Survey. Arch Gen Psychiatry $1994 ; 51: 8-19$

4. Weissman MM, Bland RC, Canino GJ, Faravelli C, Greenwald S, Hwu HG, Joyce PR, Karam EG, Lee CI, Lellouch J, Lepine JP, New man SC, Rubio-Stipec M, Wells JE, Wickramaratne PJ. Wittchen 
HU, Yeh EK: Cross-national epidemiology of major depression and bipolar disorder. JAMA 1996; 276:293-299

5. Bierut LI, Heath AC, Bucholz KK, Dinwiddie SH, Madden PAF, Statham DJ, Dunne MP, Martin NG: Major depressive disorder in a community-based twin sample: are there different genetic and environmental contributions for men and women? Arch Gen Psychiatry 1999; 56:557-563

6. Kendler KS, Neale MC, Kessler RC, Heath AC, Eaves LJ: The lifetime history of major depression in women: reliability of diagnosis and heritability. Arch Gen Psychiatry 1993; 50:863-870

7. Kendler KS, Gardner CO, Neale MC, Prescott CA: Genetic risk factors for major depression in men and women: similar or different heritabilities and same or partly distinct genes? Psychol Med 2001; 31:605-616

8. McGuffin P, Katz R, Rutherford J: Nature, nurture and depression: a twin study. Psychol Med 1991: 21:329-335

9. McGuffin P, Katz R, Watkins S, Rutherford J: A hospital-based twin register study of the heritability of DSM-IV unipolar depression. Arch Gen Psychiatry 1996; 53:129-136

10. Sullivan PF, Neale MC, Kendler KS: Genetic epidemiology of major depression: review and meta-analysis. Am J Psychiatry 2000; 157:1552-1562

11. Torgersen S: Genetic factors in moderately severe and mild affective disorders. Arch Gen Psychiatry 1986; 43:222-226

12. Mendlewicz J, Rainer JD: Adoption study supporting genetic transmission in manic-depressive illness. Nature 1977; 268: 326-329

13. Cadoret R: Evidence for genetic inheritance of primary affective disorder in adoptees. Am J Psychiatry 1978; 133:463-466

14. Wender PH, Kety SS, Rosenthal D, Schulsinger F, Ortmann J, Lunde I: Psychiatric disorders in the biological and adoptive families of adopted individuals with affective disorders. Arch Gen Psychiatry 1986; 43:923-929

15. Marazita ML, Neiswanger K, Cooper M, Zubenko GS, Giles DE, Frank E, Kupfer DJ, Kaplan BB: Genetic segregation analysis of early-onset recurrent unipolar depression. Am J Hum Genetics $1997 ; 61: 1370-1378$

16. Gershon ES, Hamovit J, Guroff JI, Dibble E, Leckman JF, Sceery W, Targum SD, Nurnberger II Jr, Goldin LR, Bunney WE Jr: A family study of schizoaffective, bipolar I, bipolar II, unipolar, and normal control probands. Arch Gen Psychiatry 1982; 39: 1157-1167

17. Weissman MM, Gershon ES, Kidd KK, Prusoff BA, Leckman JF, Dibble E, Hamovit J. Thompson WD, Pauls DL, Guroff J]: Psychiatric disorders in the relatives of probands with affective disorders: the Yale NIMH Collaborative Family Study. Arch Gen Psychiatry $1984 ; 41: 13-21$

18. Maier W, Lichtermann D, Minges J, Hallmayer J, Heun R, Benkert $\mathrm{O}$, Levinson DF: Continuity and discontinuity of affective disorders and schizophrenia: results of a controlled family study. Arch Gen Psychiatry 1993; 50:871-883

19. Cadoret RJ, Woolson R, Winokur G: The relationship of age of onset in unipolar affective illness to risk of alcoholism and depression in parents. J Psychiatr Res 1977: 13:137-142

20. Mendlewic J, Baron M: Morbidity risks in subtypes of major depression: differences between early and late onset forms. $\mathrm{Br}$ J Psychiatry 1981; 139:463-466

21. Weissman MM, Wickramaratne P, Merikangas KR, Leckman JF, Prusoff BA, Caruso KA, Kidd KK, Gammon GD: Onset of major depression in early adulthood, increased familial loading and specificity. Arch Gen Psychiatry 1984; 41:1136-1143

22. Bland RC, Newman SC, Orn $\mathrm{H}$ : Recurrent and nonrecurrent depression. Arch Gen Psychiatry 1986; 43:1085-1089

23. Kupfer DJ, Frank E, Carpenter LL, Neiswanger K: Family history in recurrent depression. J Affect Disord 1989; 17:113-119

24. Weissman MM, Wickramaratne P. Adams PB, Lish JD, Howrath E, Charney D, Woods SW, Leeman E, Frosch E: The relationship between panic disorder and major depression: a new family study. Arch Gen Psychiatry 1993; 50:767-780

25. Gershon ES, Weissman MM, Guroff JJ, Prusoff BA, Leckman JF: Validation of criteria for major depression through controlled family study. J Affect Disord 1986; 11:125-131

26. Kendler KS, Neale MC, Kessler RC, Heath AC, Eaves L]: The clinical characteristics of major depression as indices of the familial risk to illness. Br J Psychiatry 1994; 165:66-72

27. Kendler KS, Gardner CO, Prescott CA: Clinical characteristics of major depression that predict risk of depression in relatives. Arch Gen Psychiatry 1999; 56:322-327; correction, 2000; 57 : 94-95

28. Weissman MM, Kidd KK, Prusoff BA: Variability in rates of affective disorders in relatives of depressed and normal probands. Arch Gen Psychiatry 1982; 39:1397-1403

29. Risch N: Linkage strategies for genetically complex traits, I: multilocus models. Am J Hum Genet 1990; 46:222-228

30. National Institute of Mental Health Genetics Workgroup: Genetics and Mental Disorders: Report of the NIMH Genetics Workgroup. Washington, DC, National Institutes of Health. 1997

31. Levinson DF, Zubenko GS, Crowe RR, DePaulo JR, Scheftner WS, Weissman MM, Holmans P, Zubenko WN, Boutelle S, MurphyEberenz K, Mackinnon D, McInnis MG, Marta DH, Adams P, Sassoon S, Knowles JA, Thomas J, Chellis J: Genetics of recurrent early-onset depression (GenRED): design and preliminary clinical characteristics of a repository sample for genetic linkage studies. Am J Med Genet 2003; 119B:118-130

32. Nurnberger J Jr, Blehar MC, Kaufmann CA, York-Cooler C, Simpson SG, Harkavy-Friedman J, Severe JB, Malaspina D, Reich T: Diagnostic Interview for Genetic Studies: rationale, unique features, and training. Arch Gen Psychiatry 1994: 51:849-859

33. American Psychiatric Association: Diagnostic and Statistical Manual of Mental Disorders, 4th ed. Washington, DC, American Psychiatric Press, 1994

34. O'Connell JR, Weeks DE: PedCheck: a program for identification of genotype incompatibilities in linkage analysis. Am J Hum Genet 1998; 63:259-266

35. Boehnke M, Cox NJ: Accurate inference of relationships in sibpair linkage studies. Am J Hum Genet 1997; 61:423-429

36. Douglas JA, Boehnke M. Lange K: A multipoint method for detecting genotyping errors and mutations in sibling-pair linkage data. Am J Hum Genet 2000; 66:1287-1297

37. Gudbjartsson DF, Jonasson K, Frigge ML, Kong A: ALLEGRO, a new computer program for multipoint linkage analysis. Nat Genet 2000; 25:12-13

38. Kong A, Gudbjartsson DF, Sainz J, Jonsdottir GM, Gudjonsson SA, Richardsson B, Sigurdardottir S, Barnard J, Hallbeck B, Masson G, Shlien A, Palsson ST, Frigge ML, Thorgeirsson TE, Gulcher JR, Stefansson K: A high-resolution recombination map of the human genome. Nat Genet 2002; 31:241-247

39. Gudbjartsson DF, Jonasson K, Frigge ML, Kong A: Fast Multipoint Linkage Analysis and the Program ALLEGRO (Allegro technical report number). Reykjavik, Iceland, DeCode Genetics, 2000

40. Kong A, Cox NJ: Allelle-sharing models: lod scores and accurate linkage tests. Am J Hum Genet 1997; 61:1179-1188

41. Lander E, Kruglyak L: Genetic dissection of complex traits: guidelines for interpreting and reporting linkage results. Nat Genet 1995; 11:241-247

42. Holmans $P$ : Detecting gene-gene interactions using affected sib pair analysis with covariates. Hum Hered 2002; 53:92-102

43. Rice JP: The role of meta-analysis in linkage studies of complex traits. Am J Med Genet 1997; 74:112-114

44. Olson JM: A general conditional-logistic model for affected-relative-pair linkage studies. Am J Hum Genet 1999; 65:17601769 
45. Knowles JA, Vieland VJ, Gilliam TC: Perils of gene mapping with microsatellite markers. Am J Hum Genet 1992; 51:905-909

46. $\mathrm{Ott} \mathrm{J}$ : Strategies for characterizing highly polymorphic markers in human gene mapping. Am J Hum Genet 1992; 51:283-290

47. Xu JF, Taylor EW, Lung FW, Chung AS, Chase GA, Maestri NE, Meyers DA: The impact of some parameters on linkage analysis of Alzheimer's disease. Genet Epidemiol 1993; 10:407-412

48. Freimer NB, Sandkuijl LA, Blower SM: Incorrect specification of marker allele frequencies: effects on linkage analysis. Am J Hum Genet 1993; 52:1102-1110

49. Goring $\mathrm{HH}$, Terwilliger JD: Linkage analysis in the presence of errors, III: marker loci and their map as nuisance parameters. Am J Hum Genet 2000; 66:1298-1309

50. Abkevich V, Camp NJ. Hensel CH, Neff CD. Russell DL, Hughes DC, Plenk AM, Lowry MR, Richards RL, Carter C, Frech GC, Stone S, Rowe K, Chau CA, Cortado K, Hunt A, Luce K, O'Neil G, Poarch J, Potter J, Poulsen GH, Saxton H, Bernat-Sestak M, Thompson V, Gutin A, Skolnick MH, Shattuck D, Cannon-Albright L: Predisposition locus for major depression at chromosome 12q2212q23.2. Am J Hum Genet 2003; 73:1271-1281

51. Suarez BK, Hampe CL, Van Eerdewegh P: Problems of replicating linkage claims in psychiatry, in Genetic Approaches to Mental Disorders. Edited by Gershon ES, Cloninger CR. Washington, DC, American Psychiatric Press, 1994, pp 23-46

52. Goring $\mathrm{HH}$, Terwilliger JD, Blangero J: Large upward bias in estimation of locus-specific effects from genomewide scans. Am J Med Genet B Neuropsychiatr Genet 2001; 69:1357-1369

53. Zubenko GS, Maher B, Hughes HB III, Zubenko WN, Stiffler JS, Kaplan BB, Marazita ML: Genome-wide linkage survey for genetic loci that influence the development of depressive disorders in families with recurrent, early-onset major depression. Am J Med Genet B Neuropsychiatr Genet 2003; 123:1-18

54. Fullerton J, Cubin M, Tiwari H, Wang C, Bomhra A, Davidson S, Miller S, Fairburn C, Goodwin G, Neale MC, Fiddy S, Mott R, Allison DB, Flint J: Linkage analysis of extremely discordant and concordant sibling pairs identifies quantitative-trait loci that influence variation in the human personality trait neuroticism. Am J Hum Genet 2003; 72:879-890

55. Camp NJ, Lowry MR, Richards RL, Plenk AM, Carter C, Hensel $\mathrm{CH}$, Abkevich V, Skolnick MH, Shattuck D, Rowe KG, Hughes DC, Cannon-Albright LA: Genome-wide linkage analyses of extended Utah pedigrees identifies loci that influence recurrent, early-onset major depression and anxiety disorders. Am J Med Genet B Neuropsychiatr Genet 2005; 135:85-93

56. McGuffin P, Knight J, Breen G, Brewster S, Boyd PR, Craddock N, Gill M, Korszun A, Maier W, Middleton L, Mors O, Owen MJ, Perry J, Preisig M, Reich T, Rice J, Rietschel M, Jones L, Sham P, Farmer AE: Whole genome linkage scan of recurrent depressive disorder from the Depression Network (DeNt) Study. Hum Mol Genet 2005; 14:3337-3345

57. Farmer A, Breen G, Brewster S, Craddock N, Gill M, Korszun A, Maier W, Middleton L, Mors O, Owen M, Perry J, Preisig M,
Rietschel M, Reich T, Jones L, Jones I, McGuffin P: The Depression Network (DeNT) Study: methodology and sociodemographic characteristics of the first 470 affected sibling pairs from a large multi-site linkage genetic study. BMC Psychiatry 2004; $4: 42$

58. Cloninger $C R$, Van Eerdewegh $P$, Goate A, Edenberg $H$ J, Blangero J, Hesselbrock V, Reich T, Nurnberger J Jr, Schuckit M, Porjesz B, Crowe R, Rice JP, Foroud T, Przybeck TR, Almasy L, Bucholz K, Wu W, Shears S, Carr K, Crose C, Willig C, Zhao J, Tischfield JA, Li TK, Conneally PM, Begleiter H: Anxiety proneness linked to epistatic loci in genome scan of human personality traits. Am J Med Genet 1998; 81:313-317

59. Nash MW, Huezo-Diaz P, Williamson RJ, Sterne A, Purcell S, Hoda F, Cherny SS, Abecasis GR, Prince M, Gray JA, Ball D, Asherson P, Mann A, Goldberg D, McGuffin P, Farmer A, Plomin R, Craig IW, Sham PC: Genome-wide linkage analysis of a composite index of neuroticism and mood-related scales in extreme selected sibships. Hum Mol Genet 2004; 13:2173-2182

60. Neale BM, Sullivan PF, Kendler KS: A genome scan of neuroticism in nicotine dependent smokers. Am J Med Genet B Neuropsychiatr Genet 2005; 132:65-69

61. Lewis CM, Levinson DF, Wise LH, DeLisi LE, Straub RE, Hovatta I, Williams NM, Schwab SG, Pulver AE, Faraone SV, Brzustowicz LM, Kaufmann CA, Garver DL, Gurling HM, Lindholm E, Coon H, Moises HW, Byerley W, Shaw SH, Mesen A, Sherrington R, O'Neill FA, Walsh D, Kendler KS, Ekelund J, Paunio T, Lonnqvist J. Peltonen L, O'Donovan MC, Owen MJ, Wildenauer DB, Maier W, Nestadt G, Blouin JL, Antonarakis SE, Mowry BJ, Silverman JM, Crowe RR, Cloninger CR, Tsuang MT, Malaspina D, HarkavyFriedman JM, Svrakic DM, Bassett AS, Holcomb J, Kalsi G, McQuillin A, Brynjolfson J, Sigmundsson T, Petursson $H$, Jazin E, Zoega T, Helgason T: Genome scan meta-analysis of schizophrenia and bipolar disorder, part II: schizophrenia. Am J Hum Genet 2003; 73:34-48

62. Norton N, Williams HJ, Owen MJ: An update on the genetics of schizophrenia. Curr Opin Psychiatry 2006; 19:158-164

63. Levinson DF: The genetics of depression: a review. Biol Psychiatry 2006; 60:84 92

64. McQueen MB, Devlin B, Faraone SV, Nimgaonkar VL, Sklar P, Smoller JW, Abou Jamra R, Albus M, Bacanu SA, Baron M, Barrett TB, Berrettini W, Blacker D, Byerley W, Cichon S, Coryell W. Craddock N, Daly MJ, Depaulo JR, Edenberg HJ, Foroud T, Gill M, Gilliam TC, Hamshere M, Jones I, Jones L, Juo SH, Kelsoe JR, Lambert D, Lange C, Lerer B, Liu J. Maier W, Mackinnon JD, McInnis MG, McMahon FJ, Murphy DL, Nothen MM, Nurn. berger JI, Pato CN, Pato MT, Potash JB, Propping P, Pulver AE, Rice JP, Rietschel M, Scheftner W, Schumacher J, Segurado R, Van Steen K, Xie W, Zandi PP, Laird NM: Combined analysis from eleven linkage studies of bipolar disorder provides strong evidence of susceptibility loci on chromosomes $6 q$ and $8 q$. Am J Hum Genet 2005; 77:582-595 